\title{
Annual Report on the External Quality Assessment Scheme for Diagnostic Hematology in Korea (2014)
}

Gye Cheol Kwon, Jimyung Kim, and Gee Su Ra, as

Diagnostic Hematology Subcommittee, The Korean Association of Quality Assurance for Clinical Laboratory Department of Laboratory Medicine, Chungnam National University Hospital, Daejeon, Korea

Corresponding author: Gye Cheol Kwon

Department of Laboratory Medicine, Chungnam National University Hospital, 282

Munhwa-ro, Jung-gu, Daejeon 301-721, Korea

Tel: +82-42-280-7799

Fax: +82-42-257-5365

E-mail: kckwon00@naver.com

pISSN: $1225-097 X$

eISSN: 2288-7261
During 2014, the Diagnostic Hematology Subcommittee of the Korean Association of Quality Assurance for Clinical Laboratories performed laboratory proficiency testing for blood cell count, cell morphology, and coagulation tests. Four trials for blood cell count and cell morphology tests and 2 trials for coagulation tests were performed. The trials for blood cell counts had a reply rate of $96.8 \%$ among 1,343 laboratories, compared to $99.3 \%$ among 489 laboratories for cell morphology and $98.6 \%$ among 565 laboratories for coagulation tests. The homogeneity of the external quality materials was stable $(<3 \%)$, and the use of instruments and reagents was similar to that observed during the previous year. The CVs for white blood cell counts, red blood cell counts, platelet counts, hemoglobin tests, and hematocrit tests were $4.46 \%, 2.12 \%, 2.21 \%, 5.08 \%$, and $8.31 \%$, respectively. For cell morphology tests, concordant rates were $>80 \%$ for most of the participating laboratories. The CVs for the coagulation tests varied according to the specific instruments or reagents that were used. An educational workshop was held in July to provide hands-on experience in diagnostic hematology. During 2014, the number of participating laboratories was increased, while the performance of hematology tests was similar to that observed in the previous year.

(J Lab Med Qual Assur 2015;37:1-11)

Key Words: Laboratory proficiency testing, Blood cell count, Peripheral blood smear, Prothrombin time, Partial thromboplastin time

\section{서론}

2014년도 진단혈액분과위원회의 외부정도관리사업은 전 년도와 동일하게 일반혈액검사의 총 6종목(백혈구 수, 적혈 구 수, 혈색소, 적혈구용적률, 혈소판 수, 세포형태)에 대해 서는 연 4회 실시되었으며, 혈액응고시간검사는 프로트롬빈 시간(prothrombin time)과 활성화부분트롬보플라스틴시간 (activated partial thromboplastin time)의 2종목에 대하여 연 2회 실시되었다[1]. 또한 검사기관 진단혈액 실무 담당자를 대상으로 한 교육프로그램은 연 1회 진행되었다.

\section{재료 및 방법}

일반혈액검사 정도관리사업은 백혈구 수, 적혈구 수, 혈색 소, 적혈구용적률, 혈소판 수 항목을 대상으로 각각 4월, 5월, 10 월, 11 월에 총 4 회 실시하였으며, 차수당 1 개의 정도관리 물질을 평가하였다. 정도관리물질은 $\mathrm{CBC}-4 \mathrm{~K}$ Whole Blood Control (R\&D system Inc., Minneapolis, MN, USA)을 이 용하였는데 1 회차와 3 회차에는 낮은 농도의 control 물질, 2 회차에는 정상 농도의 control 물질을 포함하였으며, 4회차에 는 높은 농도의 control 물질을 포함하였다. 세포형태를 위한 정도관리사업은 4월, 5 월, 10 월, 11 월에 총 4회 실시하였으며, 매 차수마다 2 개의 이미지를 홈페이지에 게시하고 참가기관에 서 판독할 수 있게 하였다. 


\section{Journal of LABORATORY MEDICINE and QUALITY ASSURANCE}

\section{Gye Cheol Kwon et al • Annual Report on EQA in Diagnostic Hematology}

혈액응고시간검사 정도관리사업은 프로트롬빈시간, 활성 화부분트롬보플라스틴시간검사를 대상으로 4 월과 10 월에 총 2 회 실시하였으며, 정도관리물질은 1회차에는 Lyphochek Coagulation control level 3 (Bio-Rad Laboratories, Hercules, CA, USA)를 이용하였고, 3회차에는 Lyphochek Coagulation control level 1 (Bio-Rad Laboratories)를 이용 하였다. 일반혈액검사 및 혈액응고시간검사의 차수별로 이용 된 정도관리물질은 각 vial 간의 균질성을 확인하기 위하여 20 vial마다 1 vial씩 선택하여 측정하고 측정값의 평균, 표준편차 와 변이계수를 구하였다.

정도관리물질의 정확하고 신속한 운송을 위하여 계약 택배 를 이용하였으며, 1 회 및 2회차 정도관리물질은 2014년 4월 14일에, 3회 및 4회차 정도관리물질은 2014년 10월 20일에 함 께 발송하였다. 2회차 및 4회차 정도관리물질은 $4-6^{\circ} \mathrm{C}$ 냉장 보 관하였다가 정해진 해당 차수 시행일에 검사하도록 하였다. 각 회차의 검사결과는 대한임상검사정도관리협회 홈페이지에서 입력하게 하였고, 입력기간 종료 후 입력결과에 대하여 웹 브 라우저를 통해 온라인으로 데이터 오류를 검증하였으며, 검증 이 끝난 결과는 홈페이지 웹 기반 분석프로그램을 이용하여 통 계분석을 시행하였다.

일반혈액검사항목에 속하는 백혈구 수, 적혈구 수, 혈색소, 적혈구용적률, 혈소판 수에 대해서는 검사결과를 측정기기 및 측정방법으로 분류하고 각 분류군의 평균, 표준편차, 변이
계수, 최솟값, 최댓값을 구하였으며 표준편차지수(standard deviation index, SDI) 결과를 기준으로 도수분포를 구하였 다[2]. 세포형태 판독에 대한 분석은 각 세포별로 결과 도수별 기관 수와 백분율을 보고하였으며 각 기관별 분석결과는 홈페 이지를 통하여 직접 조회 및 출력할 수 있도록 하였다.

혈액응고시간검사항목인 프로트롬빈시간, 활성화부분트롬 보플라스틴시간의 검사결과는 측정기기, 측정방법 그리고 측 정시약으로 나누어 분류하고 각 분류군의 평균, 표준편차, 변 이계수, 최솟값, 최댓값을 구하였으며, 측정기기별 전체 SDI 결과를 기준으로 도수분포를 구하였다. 결과 분석 시 프로트 롬빈시간은 international normalized ratio (INR)을 이용하 여 통계분석하였으며, 활성화부분트롬보플라스틴시간은 시간 (seconds)을 통계분석하였다.

검사기관 진단혈액 실무 담당자를 대상으로 한 교육프로 그램은 다른 운영분과와 공동 협력하여 통합 워크샵으로 7월 에 진행되었으며 교육주제는 장비검사 검증을 위한 수기법 검 사의 이용이었으며, 교육내용은 수기법을 이용한 프로트롬 빈시간과 활성화부분트롬보플라스틴시간 측정, Neubauer chamber를 이용한 세포 수 측정과 감별계산, 수기법을 이용 한 microhematocrit검사와 망상적혈구검사를 포함하였다.

Table 1. Participants in the external quality assessment

\begin{tabular}{|c|c|c|c|c|c|c|c|}
\hline Evaluation & Trial & $\begin{array}{c}\text { Sample } \\
\text { delivery date }\end{array}$ & $\begin{array}{c}\text { Result } \\
\text { delivery date }\end{array}$ & $\begin{array}{c}\text { Delivered } \\
\text { participants }\end{array}$ & $\begin{array}{c}\text { Returned } \\
\text { participants }\end{array}$ & $\begin{array}{c}\text { Replying } \\
\text { participants }\end{array}$ & Reply rate (\%) \\
\hline \multicolumn{8}{|c|}{ Complete blood count } \\
\hline & 2 nd & 2014-04-14 & 2014-06-09 & 1,332 & 0 & 1,297 & 97.37 \\
\hline & $3 \mathrm{rd}$ & 2014-10-20 & 2014-11-13 & 1,353 & 3 & 1,304 & 96.59 \\
\hline & Mean & & & 1,343 & 2 & 1,299 & 96.83 \\
\hline \multicolumn{8}{|c|}{ Blood cell morphology } \\
\hline & 1 st & 2014-04-15 & 2014-05-20 & 487 & 0 & 484 & 99.38 \\
\hline & 2nd & $2014-05-13$ & 2014-06-09 & 487 & 0 & 481 & 98.77 \\
\hline & $3 r d$ & 2014-10-21 & 2014-11-13 & 491 & 0 & 489 & 99.59 \\
\hline & 1 st & 2014-04-14 & 2014-05-20 & 565 & 0 & 558 & 98.76 \\
\hline & 3 th & $2014-10-20$ & 2014-11-13 & 565 & 1 & 555 & 98.40 \\
\hline & Mean & & & 565 & 1 & 557 & 98.58 \\
\hline
\end{tabular}




\section{Journal of LABORATORY MEDICINE and QUALITY ASSURANCE}

\section{Gye Cheol Kwon et al • Annual Report on EQA in Diagnostic Hematology}

\section{결과}

\section{1. 신빙도조사 참여기관}

일반혈액검사 신빙도조사에 참여한 기관 수는 1 차 및 2 차는 1,332 기관, 3 차 및 4 차는 1,353 기관으로 평균 1,343 기 관이 참여하였다. 검체를 발송 받은 기관 중 1 차부터 4 차까
지 각각 1,307 기관(98.12\%), 1,297 기관(97.37\%), 1,304 기 관(96.59\%), 1,286 기관(95.26\%)이 결과를 회신하여 평균 $96.83 \%$ 의 회신율을 보였다.

세포형태 신빙도조사의 참여기관 수는 1차 및 2차는 487기 관, 3 차 및 4차는 491기관으로 평균 489기관이 참여하였다. 결 과 회신은 각각 484기관(99.38\%), 481기관(98.77\%), 489기

Table 2. Homogeneity for the external quality assessment materials

\begin{tabular}{|c|c|c|c|c|c|c|c|c|c|c|c|c|c|c|}
\hline \multirow[t]{2}{*}{ Trial } & \multicolumn{2}{|c|}{$\begin{array}{l}\text { White } \\
\text { blood cells }\end{array}$} & \multicolumn{2}{|c|}{$\begin{array}{c}\text { Red } \\
\text { blood cells }\end{array}$} & \multicolumn{2}{|c|}{ Hemoglobin } & \multicolumn{2}{|c|}{ Hematocrit } & \multicolumn{2}{|c|}{ Platelets } & \multicolumn{2}{|c|}{$\begin{array}{l}\text { Prothrombin time } \\
\text { (international } \\
\text { normalized ratio) }\end{array}$} & \multicolumn{2}{|c|}{$\begin{array}{c}\text { Activated partial } \\
\text { thromboplastin } \\
\text { time (s) }\end{array}$} \\
\hline & $\mathrm{SD}$ & $\mathrm{CV}$ & SD & $\mathrm{CV}$ & SD & $\mathrm{CV}$ & SD & $\mathrm{CV}$ & SD & $\mathrm{CV}$ & SD & $\mathrm{CV}$ & SD & $\mathrm{CV}$ \\
\hline $1 \mathrm{st}$ & 0.08 & 2.50 & 0.01 & 0.44 & 0.04 & 0.73 & 0.10 & 0.56 & 2.03 & 3.06 & 0.04 & 0.83 & 1.41 & 1.20 \\
\hline 2nd & 0.12 & 1.60 & 0.03 & 0.67 & 0.07 & 0.54 & 0.29 & 0.71 & 4.55 & 2.25 & - & - & - & - \\
\hline $3 r d$ & 0.08 & 2.51 & 0.01 & 0.45 & 0.06 & 1.07 & 0.11 & 0.64 & 1.89 & 2.92 & 0.01 & 0.96 & 0.18 & 0.71 \\
\hline 4 th & 0.40 & 1.79 & 0.04 & 0.78 & 0.10 & 0.63 & 0.31 & 0.65 & 6.44 & 1.61 & - & - & - & - \\
\hline
\end{tabular}

Table 3. Currently available equipment for complete blood counting and coagulation testing

\begin{tabular}{|c|c|c|c|c|c|c|c|}
\hline Program & Manufacturer & 1 st & 2nd & 3 rd & 4 th & Mean & $\%$ \\
\hline \multicolumn{8}{|c|}{ Complete blood count } \\
\hline & Sysmex Corporation & 539 & 541 & 551 & 548 & 544.75 & 41.95 \\
\hline & Siemens & 134 & 134 & 137 & 134 & 134.75 & 10.38 \\
\hline & Mindray & 117 & 116 & 124 & 120 & 119.25 & 9.18 \\
\hline & Horiba Medical & 122 & 117 & 118 & 114 & 117.75 & 9.07 \\
\hline & Nihon Kohden Co. & 120 & 116 & 113 & 113 & 115.50 & 8.89 \\
\hline & Beckman Coulter Inc. & 100 & 98 & 97 & 99 & 98.50 & 7.59 \\
\hline & Abbott Laboratories & 73 & 69 & 64 & 62 & 67.00 & 5.16 \\
\hline & Boule Medical Lab. & 35 & 36 & 32 & 32 & 33.75 & 2.60 \\
\hline & Orphee Medical & 23 & 23 & 22 & 22 & 22.50 & 1.73 \\
\hline & Drew Scientific Group & 17 & 18 & 15 & 15 & 16.25 & 1.25 \\
\hline & Others & 27 & 29 & 31 & 27 & 28.50 & 2.19 \\
\hline & Total & 1,307 & 1,297 & 1,304 & 1,286 & $1,298.50$ & 100.00 \\
\hline \multicolumn{8}{|l|}{ Coagulation time } \\
\hline & Sysmex Corporation & 202 & & 200 & & 201.00 & 36.12 \\
\hline & IL & 162 & & 164 & & 163.00 & 29.29 \\
\hline & Diagnostica Stago & 72 & & 74 & & 73.00 & 13.12 \\
\hline & Behnk Elektronik & 34 & & 36 & & 35.00 & 6.29 \\
\hline & Shimadzu Corporation & 13 & & 16 & & 14.50 & 2.61 \\
\hline & TECO & 14 & & 12 & & 13.00 & 2.34 \\
\hline & MD Pacific & 13 & & 11 & & 12.00 & 2.16 \\
\hline & Rayto & 12 & & 11 & & 11.50 & 2.07 \\
\hline & Others & 36 & & 31 & & 33.50 & 6.02 \\
\hline & Total & 558 & & 555 & & 556.50 & 100.00 \\
\hline
\end{tabular}




\section{Journal of LABORATORY MEDICINE and QUALITY ASSURANCE}

\section{Gye Cheol Kwon et al • Annual Report on EQA in Diagnostic Hematology}

관(99.59\%), 489기관(99.59\%)에서 이루어져 평균 99.34\% 의 회신율을 보였다. 혈액응고시간검사 신빙도조사의 참여기 관 수는 1 차는 565 기관, 2 차는 565 기관이었다. 이 중 558 기관 $(98.76 \%), 555$ 기관 $(98.40 \%)$ 에서 회신하여 평균 $98.58 \%$ 의 회신율을 보였다(Table 1).

\section{2. 정도관리물질의 균질성}

1 회차부터 4 회차까지 사용된 일반혈액검사 각 항목에 대한 정도관리물질의 변이계수는 다음과 같다. 백혈구 수의 변이계 수는 $2.50 \%, 1.60 \%, 2.51 \%, 1.79 \%$, 적혈구 수의 변이계수 는 $0.44 \%, 0.67 \%, 0.45 \%, 0.78 \%$, 혈색소는 $0.73 \%, 0.54 \%$, $1.07 \%, 0.63 \%$, 적혈구용적률의 변이계수는 $0.56 \%, 0.71 \%$, $0.64 \%, 0.65 \%$, 혈소판 수의 변이계수는 $3.06 \%, 2.25 \%$, $2.92 \%, 1.61 \%$ 를 각각 나타냈다. 1 회차와 3 회차에 사용된 혈 액응고검사 정도관리물질의 변이계수는 각각 프로트롬빈시 간 INR의 경우 $0.83 \%, 0.96 \%$, 활성화부분트롬보플라스틴시 간의 경우 $1.20 \%, 0.71 \%$ 를 보였다. Marshall 등[3]의 보고에 의하면 검사실 내 변이계수는 $3 \%$ 이내, 검사실 간 변이계수는 $5 \%$ 이내를 추천하였는데 평가된 변이계수는 모두 만족하는 결과를 나타내었다(Table 2).

\section{3. 기기 및 시약 이용현황}

참여기관의 일반혈액검사에 이용된 자동분석기기는 제조 사별로 분류하였을 때 Sysmex사가 $41.95 \%$ 으로 가장 많았 으며, Siemens사가 10.38\%, Mindray사가 9.18\%, Horiba Medical사가 9.07\%, Nihon Kohden사가 8.89\%, Beckman Coulter사가 $7.59 \%$ 순으로 조사되었다. 혈액응고시간 측정에 이용된 참여기관의 자동분석기기는 제조사별로 분류하였을 때 Sysmex사가 $36.12 \%$ 로 가장 많았으며, Instrumentation Laboratory사가 29.29\%, Diagnostica Stago사가 13.12\%, Behnk Elektronik사가 6.29\%으로 나타났다(Table 3). 혈 액응고시간 측정에 이용된 검사시약은 제조사별로 분류하 였을 때 Siemens사 시약의 사용이 $37.38 \%$ 로 가장 높았 으며, Instrumentation Laboratory사가 29.29\%, Pacific Hemostasis사가 $12.13 \%$ 를 나타내었다(Table 4).

\section{4. 일반혈액검사}

백혈구 수의 전체기관 변이계수는 평균 4.16\% (1차 4.01\%, 2 차 $4.18 \%, 3$ 차 $3.72 \%, 4$ 차 $4.71 \%$ )로 전년도의 $3.15 \%$ 보다 높았으며 적혈구 수의 전체기관 변이계수는 평균 2.12\% (1 차 $2.69 \%, 2$ 차 $1.77 \%, 3$ 차 $2.29 \%, 4$ 차 $1.74 \%$ )로 전년도의 $2.00 \%$ 와 유사하였다. 혈소판 수의 전체기관 변이계수도 평균

Table 4. Current reagents for analysing PT and aPTT

\begin{tabular}{|c|c|c|c|c|c|}
\hline Program & Manufacturer & 1 st & $3 \mathrm{rd}$ & Mean & $\%$ \\
\hline \multicolumn{6}{|l|}{$\mathrm{PT}$} \\
\hline & Siemens & 208 & 208 & 208.0 & 37.38 \\
\hline & Instrumentation Laboratory & 162 & 164 & 163.0 & 29.29 \\
\hline & Diagnostica Stago & 74 & 75 & 74.5 & 13.39 \\
\hline & Pacific Hemostasis & 66 & 69 & 67.5 & 12.13 \\
\hline & Sekisui Medical Co. & 14 & 16 & 15.0 & 2.70 \\
\hline & MD Pacific Hemostasis & 13 & 12 & 12.5 & 2.25 \\
\hline & Others & 21 & 11 & 16.0 & 2.88 \\
\hline & Total & 558 & 555 & 556.5 & 100.00 \\
\hline \multicolumn{6}{|l|}{ aPTT } \\
\hline & Siemens & 209 & 207 & 208.0 & 37.51 \\
\hline & Instrumentation Laboratory & 162 & 163 & 162.5 & 29.31 \\
\hline & Diagnostica Stago & 73 & 73 & 73.0 & 13.17 \\
\hline & Pacific Hemostasis & 54 & 62 & 58.0 & 10.46 \\
\hline & Sekisui Medical Co. & 14 & 16 & 15.0 & 2.71 \\
\hline & MD Pacific Hemostasis & 15 & 12 & 13.5 & 2.43 \\
\hline & Others & 30 & 19 & 24.5 & 4.42 \\
\hline & Total & 557 & 552 & 554.5 & 100.00 \\
\hline
\end{tabular}

Abbreviations: PT, prothrombin time; aPTT, activated partial thromboplastin time. 
Journal of LABORATORY MEDICINE and QUALITY ASSURANCE

Gye Cheol Kwon et al • Annual Report on EQA in Diagnostic Hematology

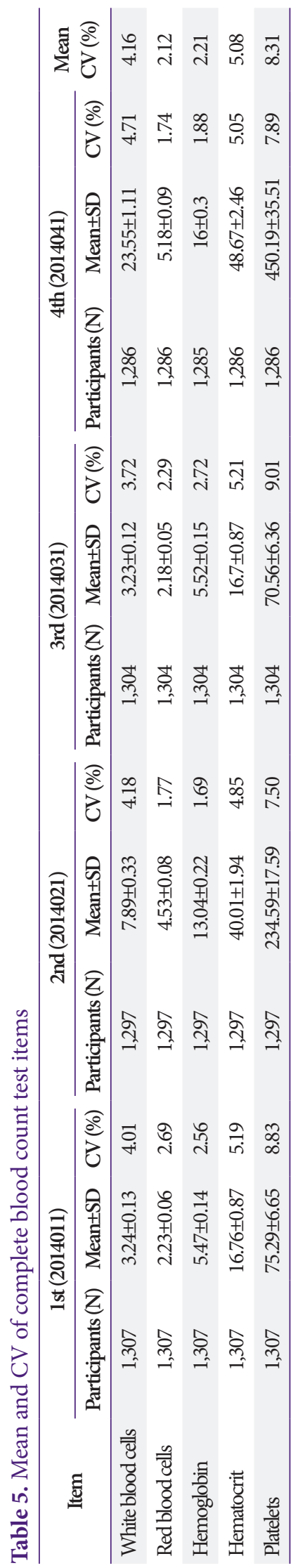

Table 6. Concordance rates of blood cell morphology

\begin{tabular}{|c|c|c|c|}
\hline Trial & Code & Morphology & Value \\
\hline \multicolumn{4}{|l|}{1 st -01} \\
\hline & 438 & Nucleated red cell & $412(85.1)$ \\
\hline & 449 & Polychromatic erythrocyte & $51(10.5)$ \\
\hline & & Others & $21(4.4)$ \\
\hline & & Total & $484(1.0)$ \\
\hline \multicolumn{4}{|l|}{1 st -02} \\
\hline & 453 & Fragmented cell (schistocyte) & $446(92.1)$ \\
\hline & 456 & Sickle cell & $24(5.0)$ \\
\hline & & Others & $14(2.9)$ \\
\hline & & Total & $484(1.0)$ \\
\hline \multicolumn{4}{|c|}{ 2nd-01 } \\
\hline & 693 & Blast & $314(65.3)$ \\
\hline & 329 & Reactive lymphocyte & $57(11.9)$ \\
\hline & 115 & Myeloblast with Auer rod & $36(7.5)$ \\
\hline & 327 & Lymphocyte & $22(4.6)$ \\
\hline & 223 & Immature monocyte & $15(3.1)$ \\
\hline & & Others & $37(7.6)$ \\
\hline & & Total & $481(1.0)$ \\
\hline \multicolumn{4}{|c|}{ 2nd-02 } \\
\hline & 106 & Segmented neutrophil & $440(91.5)$ \\
\hline & 108 & Eosinophil & $30(6.2)$ \\
\hline & & Others & $11(2.3)$ \\
\hline & & Total & $481(1.0)$ \\
\hline \multicolumn{4}{|c|}{3 rd-01 } \\
\hline & 327 & Lymphocyte & $474(96.9)$ \\
\hline & & Others & $15(3.0)$ \\
\hline & & Total & $489(1.0)$ \\
\hline \multicolumn{4}{|c|}{ 3rd-02 } \\
\hline & 224 & Monocyte & $472(96.5)$ \\
\hline & 105 & Band neutrophil & $12(2.5)$ \\
\hline & & Others & $5(1.0)$ \\
\hline & & Total & $489(1.0)$ \\
\hline \multicolumn{4}{|c|}{ 4th-01 } \\
\hline & 108 & Eosinophil & $479(98.0)$ \\
\hline & & Others & $10(2.0)$ \\
\hline \multicolumn{4}{|c|}{ 4th-02 } \\
\hline & 583 & Platelet aggregates & $468(95.7)$ \\
\hline & 582 & Platelet satellitism & $17(3.5)$ \\
\hline & & Others & $4(0.8)$ \\
\hline & & Total & $489(1.0)$ \\
\hline
\end{tabular}

Values are presented as number (\%). 


\section{Journal of LABORATORY MEDICINE and QUALITY ASSURANCE}

\section{Gye Cheol Kwon et al • Annual Report on EQA in Diagnostic Hematology}

$8.31 \%(1$ 차 $8.83 \%, 2$ 차 $7.50 \%, 3$ 차 $9.01 \%, 4$ 차 $7.89 \%)$ 로 전년도의 $5.10 \%$ 보다 높았다.

혈색소의 전체기관 변이계수는 1차 $2.56 \%, 2$ 차 $1.69 \%, 3$ 차
$2.72 \%, 4$ 차 $1.88 \%$ 로 나타났다. 평균 변이계수는 $2.21 \%$ 이었으 며 전년도의 $1.81 \%$ 보다 높았다. 적혈구용적률의 전체기관 변 이계수는 1 차 $5.19 \%, 2$ 차 $4.85 \%, 3$ 차 $5.21 \%, 4$ 차 $5.05 \%$ 를 보

Table 7. Coagulation test results according to instrument group

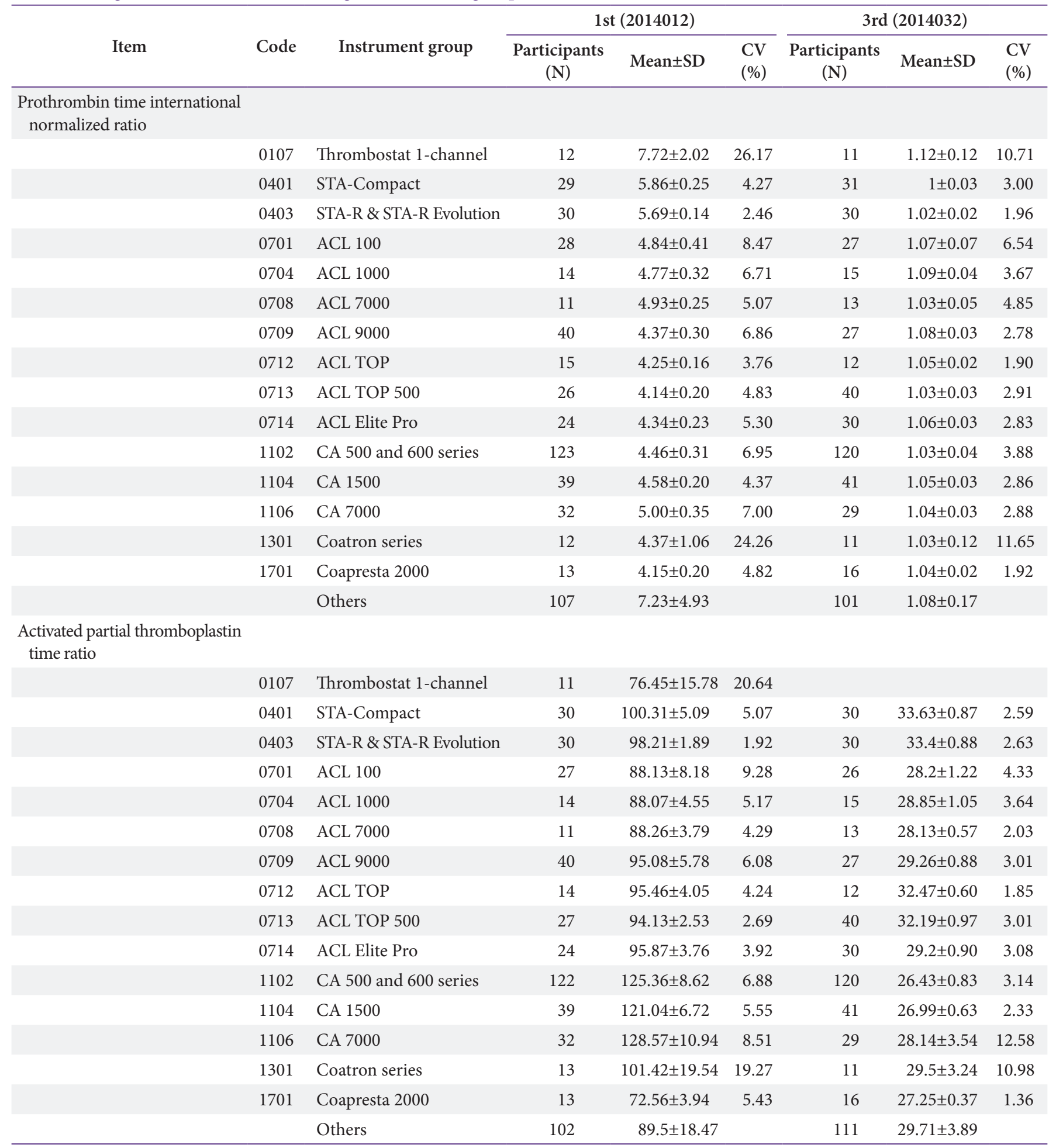




\section{Journal of LABORATORY MEDICINE and QUALITY ASSURANCE}

\section{Gye Cheol Kwon et al • Annual Report on EQA in Diagnostic Hematology}

였고, 평균은 $5.08 \%$ 로 전년도의 $2.71 \%$ 보다 높았다(Table 5).

\section{5. 세포형태}

세포형태는 매 차수마다 2개의 그림을 게시하였으며 전 체 참여기관의 $80 \%$ 이상의 일치결과를 기준으로 평가 할 때 2014년에는 1차 검체번호 [20140151]는 nucleated red cell에 85.1\%, 검체번호 [20140152]는 fragmented cell (schistocyte)에 92.1\% 일치율을 보였다. 2차 검체번 호 [20140251]는 blast에 65.3\%, reactive lymphocyte에 $11.9 \%$, 검체번호 [20140252]는 segmented neutophil에 91.5\%의 일치율을 보였다. 3차 검체번호 [20140351]는 참여 기관의 결과 중 lymphocyte에 96.9\%, 검체번호 [20140352] 는 monocyte에 $96.5 \%$ 의 일치율을 보였다. 4차 검체번호 [20140451]는 eosinophil 98.0\%의 일치율을 보였으며, 검체 번호 [20140452]는 platelet aggregates $95.7 \%$ 의 일치율을 보 였다(Table 6).

\section{6. 혈액응고시간검사}

혈액응고시간검사는 1 회차 및 3 회차에 걸쳐 총 2 회 실시하 였고, 전년도와 같이 전체 기관의 변이계수는 분석하지 않고 각 측정기기 및 측정시약별 동료집단으로 나누어 분석하였다. 기타군은 평균과 표준편차만 제시하며 변이계수분석은 제외 하였다.

프로트롬빈시간 $\mathrm{INR}$ 의 경우 측정기기별 동료집단의 변이계 수는 1회차 2.46-26.17\%, 3회차 1.90-11.65\%를 나타냈으며, 활성화부분트롬보플라스틴시간 비의 경우 측정기기별 동료집 단의 변이계수는 1회차 $1.92-20.64 \%, 3$ 회차 $1.36-12.58 \%$ 로 각 측정기기별 동료집단의 변이계수가 다양하였다. 프로트롬 빈시간 INR과 활성화부분트롬보플라스틴시간 비를 측정시약 별로 분석했을 때도 각 동료집단의 변이계수는 큰 차이를 보였다.

측정기기별 프로트롬빈시간 INR 및 활성화부분트롬보 플라스틴시간 비의 변이계수를 평가했을 때 프로트롬빈시 간 INR에 대해서는 Thrombotimer 1-Channel (Behnk Elektronik GmbH \& Co., Norderstedt, Germany)과 ACL100

Table 8. Coagulation test results according to reagent group

\begin{tabular}{|c|c|c|c|c|c|c|c|c|}
\hline \multirow[b]{2}{*}{ Item } & \multirow[b]{2}{*}{ Code } & \multirow[b]{2}{*}{ Reagent group } & \multicolumn{3}{|c|}{ 1st (2014012) } & \multicolumn{3}{|c|}{ 3rd (2014032) } \\
\hline & & & $\begin{array}{l}\text { Participants } \\
\text { (N) }\end{array}$ & Mean \pm SD & $\begin{array}{l}\mathrm{CV} \\
(\%)\end{array}$ & $\begin{array}{l}\text { Participants } \\
\text { (N) }\end{array}$ & Mean \pm SD & $\begin{array}{l}\mathrm{CV} \\
(\%)\end{array}$ \\
\hline \multicolumn{9}{|c|}{$\begin{array}{l}\text { Prothrombin time international } \\
\text { normalized ratio }\end{array}$} \\
\hline & 0202 & Thromborel-S & 206 & $4.57 \pm 0.32$ & 7.00 & 208 & $1.04 \pm 0.04$ & 3.85 \\
\hline & 0901 & Thromboplastin-D & 64 & $8.05 \pm 3.57$ & 44.35 & 69 & $1.1 \pm 0.12$ & 10.91 \\
\hline & 1301 & Coagpia PT-N & 14 & $4.12 \pm 0.21$ & 5.10 & 16 & $1.04 \pm 0.02$ & 1.92 \\
\hline & 1401 & Prothrombin time & 13 & $5.86 \pm 1.98$ & 33.79 & 12 & $1.11 \pm 0.07$ & 6.31 \\
\hline & & Others & 29 & $5.22 \pm 2.61$ & & 20 & $1.04 \pm 0.06$ & \\
\hline \multicolumn{9}{|c|}{$\begin{array}{l}\text { Activated partial } \\
\text { thromboplastin time ratio }\end{array}$} \\
\hline & 0202 & Actin FS & 16 & $74.06 \pm 10.26$ & 13.85 & 15 & $27.15 \pm 1.57$ & 5.78 \\
\hline & 0203 & Pathromtin SL & 13 & $140.88 \pm 4.68$ & 3.32 & & & \\
\hline & 0301 & STA PTT A 5 & 67 & $99.3 \pm 4.30$ & 4.33 & 69 & $33.45 \pm 0.91$ & 2.72 \\
\hline & 0702 & Synthasil & 159 & $93.14 \pm 5.39$ & 5.79 & 161 & $30.07 \pm 2.04$ & 6.78 \\
\hline & 0902 & APTT-XL & 54 & $77.03 \pm 12.59$ & 16.34 & 62 & $28.48 \pm 2.31$ & 8.11 \\
\hline & 1301 & Coagpia APTT-N & 14 & $73.48 \pm 4.83$ & 6.57 & 16 & $27.25 \pm 0.37$ & 1.36 \\
\hline & 1401 & $\begin{array}{l}\text { Activated Partial } \\
\text { Thromboplastin }\end{array}$ & 15 & $86.29 \pm 9.49$ & 11.00 & 12 & $33.7 \pm 1.85$ & 5.49 \\
\hline & & Others & 33 & $92.54 \pm 18.4$ & & 35 & $30.92 \pm 3.26$ & \\
\hline
\end{tabular}




\section{Journal of LABORATORY MEDICINE and QUALITY ASSURANCE}

\section{Gye Cheol Kwon et al • Annual Report on EQA in Diagnostic Hematology}

(Instrumentation Laboratory, Orangeburg, NY, USA), Coatron series (Teco Medical Instruments, Neufahrn, Germany)가 8.0 이상의 변이계수를 나타냈으며 활성화부분 트롬보플라스틴시간에 대해서는 Thrombotimer 1-Channel (Behnk Elektronik GmbH \& Co., Norderstedt, Germany), ACL-100 (Instrumentation Laboratory, Orangeburg, NY, USA)과 CA 7000 (Sysmex Co., Kobe, Japan), Coatron series (Teco Medical Instruments, Neufahrn, Germany)의 변이계수가 8.0 이상이었고 전년도와 차이가 없었다(Table 7).

측정시약별로 평가했을 때는 프로트롬빈시간 INR은 Pacific Hemostasis thromboplastin D (Fisher Diagnostics, Middletown, VA, USA)와 Recombiplastin 2G (Instrumentation Laboratory), Prothrombin time (MD Pacific Hemostasis)의 변이계수가 8.0 이상이었으며 활성화 부분트롬보플라스틴시간은 Actin FS (Siemens Healthcare Diagnostics, Tarrytown, NY, USA), APTT-XL (Pacific Hemostasis)과 Activated Partial Thromboplastin (MD Pacific Hemostasis)에서 변이계수가 높았고 전년도와 차이가 없었다(Table 8).

\section{고찰}

2014년에 혈액학검사 신빙도조사는 총 4회 실시하였으며, 그 중 일반혈액검사와 세포형태는 4회, 혈액응고시간검사는 2 회이었다. 세포형태는 2010년까지는 매 차수마다 5개씩 게시 하여 평가하였으나 보다 효과적인 세포형태 외부정도관리의 운영을 위해 2011년부터 매 차수마다 2개로 변경하였으며 일 치 기준은 참여기관의 $80 \%$ 이상의 보고결과로 하였다[4-7]. 일반혈액검사 및 혈액응고시간검사의 평가항목은 전년도와 동일하였다[1].

2014년의 혈액학검사 신빙도조사에는 매 차수에 평균 1,343 기관이 참여하여 2013 년의 1,308 기관보다 35 기관(2.68\%)이 증가하였고 증가율은 2013년의 5.31\%보다 감소하였다[1]. 또 한 신빙도조사의 회신율은 일반혈액검사 $96.83 \%$, 세포형태판 독 $99.3 \%$, 혈액응고시간검사 $98.6 \%$ 로 2013 년의 일반혈액검 사 $95.8 \%$, 세포형태판독 $97.8 \%$, 혈액응고시간검사 $97.4 \%$ 와 비교하여 유사한 결과를 보였다[1]. 2012년부터는 입력기간이 지난 후 미 입력기관에 대한 추가입력을 제한하는 방침을 실행 하며 참여기관이 결과 입력기간 규정을 준수하도록 입력 마감 이틀 전 미 입력기관에 입력을 독려하는 단문메시지를 전송하 고 있다. 추가 입력기간을 주지 않았음에도 신빙도조사 회신율 이 전년도와 유사한 양상을 나타낸 것은 결과 마감 공지 메시
지가 효율적이었으며 참여기관의 입력기간 준수가 정착되었 음을 반영하는 것으로 판단되었다.

검체 발송은 우체국 택배를 이용하였고, 결과접수는 대한임 상검사정도관리협회 홈페이지의 결과 입력화면을 통해 참여 기관에서 직접 결과를 입력하게 하였다. 입력기간 종료 후 입 력결과에 대하여 웹 기반 분석프로그램으로 통계분석을 시행 하였다. 결과통보는 대한임상검사정도관리협회 홈페이지 결 과조회 화면에서 참여기관별로 직접 조회 및 출력할 수 있게 하였다. 검체 발송, 결과조회, 결과입력 독촉 등 참여기관에 대 한 위원회의 전달사항 등은 단문메시지로 실무책임자의 휴대 폰으로 전송하여 전달하였으며 단문메시지 전송을 위해 참여 기관에서는 참여 신청 시 반드시 실무책임자의 휴대폰 번호를 입력하도록 공지하였다.

일반혈액검사 외부정도관리물질로는 R\&D system사의 $\mathrm{CBC}-4 \mathrm{~K}$ whole blood control을, 혈액응고시간검사 외부 정도관리물질로는 $\mathrm{BIO}-\mathrm{RAD}$ 사의 Lyphochek coagulation control을 사용하였으며 사용된 관리물질의 vial 간 균질성은 평가하기 위해 20 vial마다 1 vial씩 측정하여 변이계수로 평가 하였다. 변이계수는 표준편차를 평균값으로 나누어 백분율로 표시하는 일종의 상대적인 지수로 이 지수를 이용하여 검사결 과가 실질적인 변화인지 측정상의 변화 때문인지 알아낼 수 있 다. 변이계수는 동일 검체를 반복 검사했을 때 결과치의 변동 범위를 의미하므로 일반적으로 정도관리물질의 반복 측정에 서 얻어진 변이계수가 낮을수록 물질의 의미 있는 변화가 없음 을 반영한다고 할 수 있다. 본 외부 신빙도조사에 사용된 일반 혈액검사와 혈액응고시간검사의 정도관리물질의 변이계수는 검사실 간 $3 \%$ 이내, 검사실 내 $5 \%$ 이내 기준을 만족하는 결과 를 보여 각 vial 간의 균질성은 잘 유지되는 것으로 평가되었다.

2014년도에는 참여기관이 결과 입력 시 소수점을 빼고 입력 하거나 단위를 잘못 판단하여 입력한 경우와 같이 입력 오류를 범하였을 때에는, 분과위원회에서 결과 입력기간이 종료된 이 후 이를 수정하지 않고 각 참여기관에 입력 오류를 통보하여 추후 재발하지 않도록 조치를 취하였다.

2012년부터 본 분과는 각 기관에서 입력한 자료 중 입력 오 류로 판단되는 것은 수기로 제거하고, 이상치(outlier)에 해당 하는 입력 자료는 Tukey [8]의 "box-plot 방식을 이용한 사분 위법'의 이상치 제거를 적용하여 통계분석에서 제외하였다. 이 상치 제거는 최종 분석 시 1 사분위수와 3 사분위수의 $2 \mathrm{SD}$ 범 위를 벗어나는 기관은 통계분석에서 제외하는 방식이며 통계 범위에 들어오는 기관만을 대상으로 평균과 표준편차, 변이계 수를 측정하고 각 기관의 평가결과는 SDI로 게시하였다. 이에 따라 2014년도 각 항목별 측정기기별 통계를 분석한 결과, 일 


\section{Journal of LABORATORY MEDICINE and QUALITY ASSURANCE}

\section{Gye Cheol Kwon et al • Annual Report on EQA in Diagnostic Hematology}

반혈액검사의 결과를 회신한 평균 1,298 기관 중 통계포함기관 은 $96.77 \%$, 통계제외기관은 $3.23 \%$ 였고 혈액응고시간검사의 결과를 회신한 기관 중 평균 447기관(기타그룹은 제외) 중 통 계포함기관은 $97.09 \%$, 통계제외기관 $2.91 \%$ 이었다.

기기 및 시약 이용현황을 살펴보면 일반혈액검사에 이용 된 자동분석기기는 제조사별로 분류하였을 때 Sysmex사가 $42.0 \%$ 으로 가장 많았으며 Siemens사가 $10.4 \%$, Mindray 사가 9.2\%, Horiba Medical사가 9.1\%, Nihon Kohden사가 $8.9 \%$, 등의 순으로 조사되었다. 특징적인 것은 Mindray사 의 자동분석기기의 사용이 2008년 이후 지속적으로 상승 추세 인 점이다. 혈액응고시간 측정에 이용된 자동분석기기는 제조 사별로 분류하였을 때 Sysmex사가 $36.1 \%$, Instrumentation Laboratory사가 29.3\%, Diagnostica Stago사가 13.1\%, Behnk Elektronik사가 6.3\% 등의 순으로 장비 현황은 전년 도와 비슷한 결과였으며, 시약현황도 Siemens사가 $37.4 \%$, Instrumentation Laboratory사가 29.3\%, Diagnostica Stago 사가 $13.4 \%$, Pacific Hemostasis사가 $12.1 \%$ 등의 순으로 구 성되어 전년도와 비슷한 결과였다.

국내에서 사용하고 있는 혈액응고 기기와 시약의 종류의 다 양성은 전체기관의 평균과 표준편차에 영향을 주며, 변이계 수 또한 불안정하였다. 실제로 국외 외부정도관리 프로그램 College of American Pathologists (CAP)의 경우 측정기기 및 시약이 동일한 동료집단별로 통계분석을 수행하며 10 개 기 관 미만의 경우 별도의 변이계수는 제공하지 않는다. 동종의 기기와 시약을 사용하는 동료집단으로 분류하여 정도관리를 평가하는 것이 최적이므로 이에 근거하여 국내의 혈액응고 외 부정도관리 프로그램도 분석방식을 개선하는 것이 필요하다 고 판단되었다. 또한 현재 국내 외부정도관리는 활성화부분트 롬보플라스틴시간의 경우 활성화부분트롬보플라스틴시간 비 로 평가하나 CAP을 포함한 국외의 외부정도관리는 활성화부 분트롬보플라스틴시간으로 평가하고 있었다. 이에 따라 평가 단위를 기존의 활성화부분트롬보플라스틴시간 비 외에 활성 화부분트롬보플라스틴시간으로 구분하여 혈액응고 측정기기, 측정방법 그리고 측정시약별로 변이계수를 평가한 결과 활성 화부분트롬보플라스틴시간 비보다는 활성화부분트롬보플라 스틴시간이 보다 낮은 변이계수를 나타냈다.

2014년부터 혈액응고시간검사에 대한 분석 시 측정기기, 측 정방법, 측정시약에 따른 동료집단으로 분류가 어려운 기타 기 관은 전체 기관 통계분석에서 제외시키며 기타 기관에 대해서 는 통계범위와 변이계수를 제공하지 않고 SDI분석은 전체 기 관의 평균과 표준편차를 적용하며 혈액응고시간검사 항목 중 활성화부분트롬보플라스틴시간은 시간(seconds)으로 결과를
입력하는 개정이 필요하다고 판단되었다.

2014년도 혈액응고시간검사의 측정기기와 시약별 변이계 수를 분석했을 때 변이계수가 가장 높은 측정기기는 프로트 롬빈시간에 대해서는 Thrombostat 1-channel과 Coatron series였고 활성화부분트롬보플라스틴시간도 Thrombostat 1-channel과 Coatron series였다. 또한 측정시약은 프로트롬 빈시간에 대해서는 Thromboplastin-D, Prothromnin time이 었고 활성화부분트롬보플라스틴시간에 대해서는 Actin FS, APTT-XL과 Activated Partial Thromboplastin의 변이계수 가 가장 높았다. 그러나 기기나 시약별 변이계수가 응고항목 및 회차별로 일관되지 않아 기기나 시약이 높은 변이계수를 유 발했다고 판단할 수 없었다. 추후 기기나 시약별 변이계수의 누적 자료를 축적하는 것이 평가에 필요할 것으로 판단되었다.

대한임상검사정도관리협회 진단혈액분과의 외부정도관 리에 참가한 1,357 기관 중 2 회 이상 외부정도관리에 참여한 1,339 기관(98.67\%)이 진단혈액분과 외부정도관리 참여증 발 급대상이었고 18 기관(1.33\%)은 발급대상에서 제외되었다. 검 체 검사 수탁인증 평가대상은 1,357 기관 중 3 회 이상 참여를 하고, 70 점 이상 평가를 받은 1,213 기관(89.39\%)이 진단혈액 분과 검체 검사 수탁인증대상 기관이었고 144 기관(10.61\%) 은 제외가 되었다.

예년에는 분과별 교육 워크샵을 분리하여 수행했으나 2013 년부터는 다른 운영분과와 협력하여 통합워크샵으로 변경하 였다. 통합워크샵의 참석 만족도는 높았는데 참가기관 실무 담 당자의 교육에 참여할 수 있는 시간이 제한적임을 고려할 때 보다 높은 참여를 유도하기 위해서는 계속적인 통합워크숍을 진행하는 것이 적절하다고 생각되었다. 2014년도 진단혈액분 과의 외부정도관리사업에 참여한 기관 수는 전년도보다 증가 되었으며 수행능 결과는 전년도와 유사하였다.

2014년도 진단혈액분과위원회의 회의 안건으로 동료집단 의 $\mathrm{SDI}$ 의 정확도는 양호하게 평가되었지만 전체기관의 $\mathrm{SDI}$ 는 평가기준보다 크거나 작아 기관결과가 불량으로 평가되어 이로 인한 문의가 증가되어 진단혈액학분과위원회는 2 차 회 의를 거쳐 대한임상검사정도관리협회 운영위원회에 상정하였 으며 3차 회의에서 논의한 결과 기관별 결과지에 "전체 SDI도 의미가 있으나 기기별, 시약별 특성을 감안하여 peer group SDI도 의미가 있습니다.”라는 내용을 2014년 3차부터 병기하 며, peer group이 10기관 이하인 경우 “단 peer group이 10기 관 이하인 경우 통계적으로 신뢰도가 낮으므로 peer group 판 단을 할 수 없습니다.”라는 내용을 추가하기로 하였다. 그리 고 차세대 전산 프로그램 시행 시 평가기준은 전체 $\mathrm{SDI}$ 에 포 함되었는지를 평가하고 제외된 경우 peer group이 양호한 경 


\section{Journal of LABORATORY MEDICINE and QUALITY ASSURANCE}

\section{Gye Cheol Kwon et al • Annual Report on EQA in Diagnostic Hematology}

우 acceptable한 결과로 평가하며, 두 가지 모두 불량인 경우 unacceptable한 결과로 보고하기로 하였고 마지막으로 수탁 기관의 평가방법은 현행대로 하기로 하였다.

\section{감사의 글}

2014년에도 진단혈액분과사업을 성공적으로 수행하는 데 행정적으로 도움을 주신 충남대학교병원 관계자 여러분, 검체 포장 및 발송업무에 노고가 많았던 진단검사의학과 직원들께 감사 드리며 진단혈액 정도관리사업의 발전을 위하여 지원을 아끼지 않으신 본회 관계자 여러분께도 감사드린다.

\section{진단혈액분과위원회 위원(2014)}

권계철(위원장, 충남대학교병원), 나기수(간사, 충남대학교 병원), 이영경(한림대학교 의과대학), 김명신(가톨릭대학교 의과대학 서울성모병원), 박지영(한림대학교 의과대학), 송운 홍(신한대학교), 양미숙(연세대학교 의과대학 세브란스병원), 장윤환(원자력병원), 조영욱(울산대학교 의과대학 서울아산병 원), 함천경(김천대학교), 황상미(분당서울대학교병원)

\section{REFERENCES}

1. Kwon GC, Kim J, Ra GS; Diagnostic Hematology Subcommittee, The Korean Association of Quality Assurance for Clinical Laboratory. Annual report on external quality assessment in diagnostic hematology in Korea (2013). J
Lab Med Qual Assur 2014;36:1-11.

2. Klee GG, Westgard JO. Quality management. In: Burtis CA, Ashwood ER, Bruns DE, editors. Teitz textbook of clinical chemistry and molecular diagnostics. 5th ed. St. Louis: Elsevier Saunders, 2012:163-203.

3. Marshall SM, Barth JH. Standardization of HbAlc measurements: a consensus statement. Diabet Med 2000; 17:5-6.

4. Kwon GC, Kim JM, Park YB, Park JY, Song WH, Yoon SY, et al. Annual report on external quality assessment in hematology in Korea (2009). J Lab Med Qual Assur 2010; 32:25-43.

5. Kwon GC, Kim JM, Ra GS, Park JY, Song WH, Yoon SY, et al. Annual report of external quality assessment in diagnostic hematology in Korea (2010). J Lab Med Qual Assur 2011;33:207-32.

6. Kwon GC, Kim JM, Ra GS, Park JY, Song WH, Yoon SY, et al. Annual report of external quality assessment in diagnostic hematology in Korea (2011). J Lab Med Qual Assur 2012;34:229-34.

7. Kwon GC, Kim JM, Ra GS, Park JY, Song WH, Yoon SY, et al. Annual report of external quality assessment in diagnostic hematology in Korea (2012). J Lab Med Qual Assur 2013;35:247-74.

8. Tukey JW. Exploratory data analysis. Reading: AddisonWesley, 1977. 


\section{진단혈액학분과 신빙도조사 결과보고(2014)}

\section{권계철 - 김지명 - 나기수 • 대한임상검사정도관리협회 진단혈액학분과위원회}

충남대학교병원 진단검사의학과

임상정도관리협회 진단혈액분과는 2014년도에 일반혈액검사, 세포형태 및 혈액응고시간검사검사에 대한 신빙도조사를 시행하였다. 일반혈액검사와 세포형태는 4회, 혈액응고시간검사검사는 2회 평가 되었으며 평균 1,343기관, 489기관, 565기관이 일반혈액검사, 세포형태 및 혈액응고시간검사에 각 각 참여하였고 회신율은 각각 $96.8 \%, 99.3 \%, 98.6 \%$ 이었다. 정도관리물질의 각 vial 간의 균질성은 $3 \%$ 미만으로 안정하였으며, 사용된 장비나 시약의 현황은 전년도와 비슷하였다. 백혈구 수, 적혈구 수, 혈소판 수, 혈색소, 적혈구용적률의 변이계수는 각각 4.16\%, 2.12\%, 2.21\%, 5.08\%, 8.31\%이

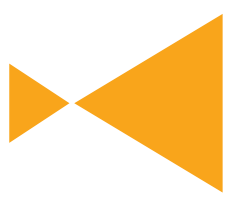

Journal of LABORATORY MEDICINE and

QUALITY ASSURANCE 었다. 세포형태는 참여기관 간 대부분 $80 \%$ 이상 일치율을 보였으며 혈액응고검사의 변이계수는 기 기 혹은 시약군별로 차이를 보였다. 통합교육 워크솝은 진단혈액검사의 실무와 관련된 주제로 7월에 실시되었다. 전년도에 비해 2014년도 외부정도관리사업 참여기관의 수는 증가하였으며 혈액학검사 의 수행능은 유사하였다.

(J Lab Med Qual Assur 2015;37:1-11)

교신저자: 권계철

우)301-721 대전시 중구 문화로 282, 충남대병원 진단검사의학과

Tel: 042)280-7799, Fax: 042)257-5365, E-mail: kckwon00@naver.com 